\title{
Physical landscape associations with mapped ecosystem values with implications for spatial value transfer: An empirical study from Norway
}

\author{
[Word count: Approximately 8,500] \\ Greg Brown* \\ School of Geography, Planning and Environmental Management \\ The University of Queensland \\ Brisbane, QLD 4072 \\ greg.brown@uq.edu.au Ph: 0733656654 \\ Vera Helene Hausner \\ Department of Arctic and Marine Biology, Arctic University of Norway, Troms $\emptyset$, Norway \\ vera.hausner@uit.no \\ Eiliv Lægreid \\ Department of Arctic and Marine Biology, Arctic University of Norway, Troms $\varnothing$, Norway \\ eiliv.laegreid@gmail.com
}

*Corresponding author 


\title{
Physical landscape associations with mapped ecosystem values with implications for spatial value transfer: An empirical study from Norway
}

\begin{abstract}
The identification of spatial associations between perceived ecosystem values and physical landscapes is confronted by a diversity of mapping methods, heterogeneous human populations, and variability in physical landscape classification systems. This study reviews previous research on spatial associations and reports new empirical findings from Norway to describe the potential for spatial "value transfer" methods that extrapolate ecosystem values to other locations. Public participation GIS (PPGIS) survey methods were implemented in two separate study areas in Norway to identify ecosystem values and to analyze their spatial association with land cover data. The ecosystem value associations with land cover were generally consistent with global findings reported elsewhere, with forested areas providing multiple ecosystem "bundles" supporting both recreation-related and provisioning values. Alternative value transfer methods were demonstrated using recreation value to compare actual with predicted distributions using land cover indices derived from value proportions, deviations from expected distribution, and correlation coefficients with ecosystem value bundles. The use of simple ecosystem value percentages located within land cover classes provided the best predictive results for value transfer in this study. The limitations and potential for value transfer methods based on spatial associations between mapped ecosystem values and physical landscape characteristics are discussed.
\end{abstract}

Keywords: ecosystem services, land cover, social values, PPGIS, value transfer 


\section{Introduction}

Over the last two decades, significant research has focused on identifying and measuring ecosystem services that provide necessary and beneficial services for human well-being (see e.g., Costanza et al., 1997; De Groot et al., 2002; Millennium Ecosystem Assessment (MEA), 2005; Wallace, 2007; Fisher et al., 2009; Kumar, 2010; Haines-Young and Potschin, 2013). Parallel to this research, advances in geospatial technologies and spatially-explicit public participation methods have encouraged experimentation with methods to identify and map the distribution of ecosystem values, especially cultural ecosystem values (Brown and Fagerholm, 2015). The purpose of this paper is to review studies that have examined the relationship between mapped ecosystem values and physical landscape characteristics as a context for reporting empirical research conducted in Norway. The spatial associations found in Norway are used to demonstrate the potential and limitations for inferring ecosystem values from land cover through a process known as spatial value transfer (Troy and Wilson, 2006).

The concept of ecosystem "service" and "value" are often conflated in the literature. The terms are related, but not identical. Ecosystem services are the "benefits people obtain from ecosystems" (MEA, 2005, p. 49) that consist of "the conditions and processes through which natural ecosystems, and the species that make them up, sustain and fulfil human life" (Daily, 1997, p. 3). Ecosystem values are measures of how important ecosystem services are to people and contain both use and non-use values associated with ecosystems. The participatory mapping of ecosystem values is particularly useful for identifying cultural ecosystem services under the assumption that the values elicited identify spatially-explicit ecosystem properties that contribute to human well-being. Thus, mapped ecosystem values identify the spatial location of ecosystem services.

The ecosystem services and values terminology has been further complicated by participatory mapping studies that have used similar value typologies but with different labels. For example, value typologies have been variously described as landscape values (Alessa et al., 2008; Brown, 2005; Zhu, et al., 2010), landscape services (Fagerholm et al., 2012), place values (Brown and Reed, 2012), community values (Raymond et al., 2009), social values for ecosystem services (Sherrouse et al., 2011; van Riper et al., 2012), or simply social values (Bryan et al., 2010). In practice, participatory mapping typologies disproportionately contain values associated with cultural ecosystem services as described in the MEA (2005). The supporting rationale is that of the four major classes of ecosystem services described in the MEA (i.e., provisioning, regulating, supporting, and cultural), the general public has a 
stronger capacity to identify provisioning and cultural services that are grounded in the experience of living in a region (Brown et al., 2012). Participatory mapping appears ideally suited to identity cultural ecosystem services because mapped values are relationship values (Brown and Weber, 2012) that bridge held values (what is important to the person) and assigned values (landscape features that are important). For consistency, we refer to values that are mapped and linked to spatially-explicit landscape features using participatory methods as ecosystem values throughout this article.

The incorporation of cultural ecosystem values into formal ecosystem assessments faces significant barriers including often vague definitions and indefinite relationships between ecosystem structures and functions and human needs and wants (Daniel et al., 2012). Further, individuals perceive social values differently according to their backgrounds, even at homogeneous local scales (Plieninger et al., 2013). Methodological challenges include over-reliance on case study research methods that have low external validity or the ability to extrapolate to other populations, settings, and conditions. Because most cultural ecosystem values are not directly observable in the physical landscape, they require either (1) proxy or indicator measures derived from observed or inferred human behavior, or (2) direct human inquiry about the benefits received. Both approaches involve epistemological assumptions with implications for the internal validity of the values collected. For example, Raudsepp-Hearne et al. (2010) used proxy measures for cultural ecosystem services such as the number of tourist attractions within a given area for tourism benefits and the number of observations of rare species for nature appreciation benefits. Are these valid and accurate proxy measures for the spatial distribution of ecosystem services? Direct methods for assessing cultural ecosystem values often involve spatiallyexplicit participatory mapping where best practice has yet to coalesce (Brown and Fagerholm, 2015).

In describing physical landscapes, there are also barriers including the availability of spatial data and standardization in collection and reporting. Where physical landscape spatial data does exist, there are often multiple classification systems, collected at multiple scales, at different points in time. While the availability and standardization of spatial data has increased, especially at a national level, the availability of local spatial data is often a limiting factor, especially in data poor developing countries. For example, although land cover is one of the most common spatial data layers for GIS applications, until recently, there was no uniform, global land cover classification system at a spatial resolution useful for analyzing ecosystem values. And while standardization of spatial data is important for interregional or international analyses, standardization can also be a limiting factor through omission of less common, but locally or regionally important physical landscape features. 


\subsection{Participatory Mapped Ecosystem Values and Physical Landscape Relationships}

There have been multiple empirical studies where ecosystem values have been identified using spatially-explicit mapping methods, commonly referred to as public participation GIS (PPGIS) (NCGIAa; NCGIAb; Obermeyer, 1998), participatory GIS (PGIS) (Rambaldi et al, 2006), or volunteered geographic information (VGI) (Goodchild, 2007). All three of these terms describe methods for generating and/or using non-expert spatial information for wide range of applications. As described by Brown and Kyttä (2014), the use of the terms PPGIS and PGIS often reflect the situational context. The term PGIS has been associated with practice in developing countries that emphasize social learning and community engagement, primarily in rural areas, with the resulting maps a potentially useful, but secondary outcome of the process. In contrast, PPGIS has focused on populations in developed countries with an emphasis on the generation of spatial data intended to inform future land use through enhanced public participation methods whose purpose is to improve the quality of land use decisions. The term volunteered geographic information (VGI) describes the harnessing of tools to create, assemble, and disseminate geographic data provided voluntarily by individuals (Goodchild (2007). PPGIS and PGIS mapping studies often include a volunteer sample or VGI component and ecosystem values have been mapped using methods described as PPGIS/PGIS/VGI (Brown and Fagerholm, 2015).

Research to date on mapped ecosystem values is limited, in part, because participatory mapping is relatively recent with the first mapping study of values occurring in 1998 (Brown, 2005). Of the 30 participatory mapping studies of ecosystem values reviewed by Brown and Fagerholm (2015), less than half analyzed the participatory mapped data for relationships with physical landscape features. Table 1 
provides descriptive information for participatory mapping studies where the spatial data were analyzed for association with physical landscape features.

\section{[Insert Table 1]}

Ecosystem value locations can be mapped with either points or polygons, but with one exception, participatory mapping studies that have assessed relationships with physical landscapes have used points to identify locations. The mapped points are assumed to represent a spatial area of ecosystem value and can be combined with other proximate points to provide a spatial estimate of the ecosystem value area. In contrast, physical landscape data is generally represented as raster or polygon data, with the exception of roads (polylines). The most common physical data that has been analyzed with mapped values is land use/land cover, but other landscape features have included roads, water bodies, landform, elevation, vegetation, built infrastructure, and GIS modeled locations of physical data such as species distributions and carbon storage. The relationships of mapped ecosystem values to administrative boundaries such as protected areas (see e.g., Brown et al., 2014; Palomo et al., 2013; Hausner et al., in press) or municipalities (e.g. Raudsepp-Hearne et al. 2010; Martin-Lopez et al. 2012; Quiroz et al. 2015) have also been analyzed in multiple studies.

Two approaches have emerged in practice for assessing mapped ecosystem values and physical landscape relationships. The SolVES model (http://solves.cr.usgs.gov/) was developed by U.S. Geological survey as a raster-based model that quantifies the relationship between the density of mapped ecosystem values, aggregated into a "value index", and physical landscape metrics such as elevation, slope, distance to roads, and distance to water (Sherrouse et al., 2011). The SolVES model has evolved and now includes Maxent maximum entropy modeling and the option to include potentially different environmental variables such as land cover and landform (Sherrouse et al, 2014). The SolVES model has been applied to participatory mapped data from national parks in Australia (van Riper et al., 2012) and the U.S. (van Riper and Kyle, 2014), and national forests in Colorado and Wyoming (Sherrouse et al., 2011; Sherrouse et al., 2014). A more recent SolVES study examined relationships between mapped ecosystem values and the modeled environmental variables of carbon sequestration and storage, scenic viewsheds, sediment regulation, and water yield (Bagstad et al, 2015). This study found weak relationships between perceived and physically modeled services, suggesting that public perception of ecosystem service provisioning regions is limited. 
To date, the use of SolVES models has provided limited insight into ecosystem values and physical landscape relationships for several reasons. First, published SolVES studies have only reported relationships between a selected subset of individual ecosystem values and landscape features. For example, the national park and national forest studies reported a maximum of three value/landscape relationships in each study. A second limiting factor is the SolVES choice of landscape features to examine potential relationships. The landscape variables of elevation, slope, distance to water, and distance to roads are widely available spatial data for modeling, but are not particularly useful variables because they are too general. Slope and elevation are continuous, rather than discrete variables with limited ability to detect relationships with landscape features that do not have distinctive boundaries associated with changes in slope or elevation. The distance to a landscape feature variable is also not a great choice, especially when the object of interest lacks specificity. For example, there are different types of water bodies (e.g., rivers, lakes, oceans) and it is water body type, not necessarily the distance to water that drives the relationship. Further, distance to water may be less important than the ability to see the water, as reported by Brown and Brabyn (2012b). When elevation and distance variables are analyzed, SolVES produces zonal statistics (means or frequencies) that can mask more specific, underlying relationships with specific landscape features.

An alternative approach for examining relationships between mapped ecosystem values and landscape characteristics quantifies the distribution of ecosystem values within landscape class layers such as land cover, landform, water bodies, water views, and infrastructure (Brown and Brabyn, 2012b). With a landscape classification system, one can assess the direct spatial concurrence of mapped ecosystem values with multiple landscape classes or features rather than distance to landscape features which is generated by SolVES. Further, landscape classes provide for hypothesis testing about whether certain types of ecosystem values are more or less abundant in the landscape classes than would be expected. The mapped locations of ecosystem values can be statistically analyzed against randomness, expected counts from mapping, or expected counts based on the proportion of area occupied by the landscape feature. Using this type of analysis, Palomo et al. (2014) reported land uses in Spain with the highest richness of ecosystem services were associated with wetlands, inland waters, and shrublands, while urban areas and agricultural lands had the lowest richness. In Germany, Plieninger et al. (2013) found that recreation, aesthetic, and education values were related to water bodies consisting of fishing ponds and lakes, while social values were related to settlement. In New Zealand, Brown and Brabyn (2012b) found greater than expected ecosystem values associated with urban areas, water features, 
native vegetation, and mountains, and fewer than expected values associated with flatter, agricultural landscapes. This latter relationship was consistent with the Plieninger et al. (2013) study that found weak relationships with croplands and grasslands. In Colorado (U.S.), Brown et al. (2012) found open water had proportionately higher recreation values while developed areas had proportionately more cultural values. In Alaska, Alessa, et al. (2008) found significant, positive relationships between mapped biological diversity values and net primary productivity.

With place-specific case studies, the validity of the findings is geographically limited to the study area and the target study population. Further, case studies invite customization with differences in how the ecosystem values are defined and operationalized in the participatory methods. In the only meta-analysis of multiple studies, Brown (2013) examined the relationship between mapped ecosystem values and global land cover in 11 different studies. The analysis used land cover as a common landscape feature and ecosystem values with similar definitions, and thus had the capacity to identify spatial associations that transcended specific geographic locations. While there was significant intraand inter-study variability, some clear relationships emerged from the analysis. For example, agricultural lands contained significantly fewer aesthetic values, forested areas and especially water bodies, contained significantly greater abundance of ecosystem values of all types, and areas of permanent snow/ice contained fewer ecosystem values of all types.

\subsection{Physical landscape associations with ecosystem service "bundles"}

Participatory mapping studies have consistently shown spatial correlations between multiple ecosystem values, thus, it is useful to explore potential spatial associations between multiple, spatially clustered ecosystem values and physical landscapes. Ecosystem services that repeatedly appear together across space or time are known as ecosystem service bundles (Raudsepp-Hearne et al., 2010) and they capture how different ecosystem services interact. Bundles appear to be distinct from inventories of individual ecosystem services that are simply added because they avoid double counting by taking into account the varying social values placed on different ecosystem services (De Groot et al., 2002). The patterns of spatial association among ecosystem services result from the interaction between multi-functional landscapes (Potschin and Haines-Young, 2013) and socio-cultural factors that include diverse individual perceptions, knowledge, and associated values (Martín-López et al., 2012).

To determine whether the same ecosystem values appear together in space, there are several options depending on the structure of the spatial data. If the mapped ecosystem values are points, one 
can calculate correlations between pairs of ecosystem values occupying the same spatial units such as a grid cells. Another alternative is to generate hotspots from the point data and then randomly sample locations across the spatial extent of the study area to calculate cross-correlation coefficients (Alessa et al. 2008). The magnitude of the correlation coefficient indicates the extent to which the pairs of services appear in the same location. Another method is to use principal component analysis (PCA) of quantified ecosystem service counts in multiple land units to identify strong correlates of the principal components, followed by cluster analysis of the results (Raudsepp-Hearne et al., 2010; Plieninger et al, 2013; Turner et al., 2014; Queiroz et al., 2015). Multiple correspondence analysis (MCA) can also be used to visualize associations between individual ecosystem values and categorical variables representing the physical landscape. Both PCA and MCA can be used to create discrete classes based on different clustering methodologies (e.g. Raudsepp-Hearne et al., 2010). Canonical correspondence analysis or redundancy analysis that bundle values in relation to multiple explanatory factors have been used to a lesser extent (but see Martin-Lopez et al., 2012).

Multiple empirical studies have reported bundled spatial distributions of ecosystem services across the study area. For example, Raudseppe-Hearne et al. (2010) identified six ecosystem bundle types using proxy ecosystem data for 137 municipalities in Canada. In Spain, Martín-López et al. (2012) identified three bundles of ecosystem services for urban populations, rural people in multifunctional landscapes, and provisioning services related to food (agriculture and fishing). In Germany, Plieninger et al., (2013) identified two ecosystem service bundles_ an activity-based recreational bundle and a second bundle that appeared related to the cognitive meanings of landscapes and ecosystems. In Denmark, Turner et al., (2014) identified six ecosystem service bundle types for specialized areas of agricultural production, coastal cultural services, multifunctional mixed-use bundles around urban areas, and forest recreation bundles with high hunting potential. In Norway, Hausner et al., (in press) reported ecosystem service bundles related to cognitive meanings of landscapes and bundles associated with historical rights to provisioning services in land tenures. And in Sweden, Queiroz et al., (2015) found multifunctional ecosystem service bundles in human-dominated landscapes, while densely populated urban areas were hotspots for cultural services. In this study, we first analyze the Norwegian spatial data for the presence of ecosystem value bundles, and then examine whether these bundles are spatially associated with land cover. 


\subsection{Research questions}

This study seeks to provide additional insight into the relationship between ecosystem values and physical landscape characteristics by analyzing data from two participatory mapping studies in Norway and to evaluate the use of ecosystem value and land cover spatial associations for the purpose of value transfer. Our analysis was guided by the following research questions: (1) what are the spatial associations between mapped ecosystem values and land cover in two case study areas in Norway and are these associations consistent with other reported studies? (2) what types of ecosystem value bundles are present in the two study areas, how do these bundle types compare to other studies, and are these bundles spatially associated with land cover? (3) can empirical spatial associations between ecosystem values and land cover be used for the purpose of "value transfer" mapping to geographic areas where primary ecosystem value data does not exist? and (4) given the results of the value transfer analyses, what are the implications for the future use of value transfer methods for ecosystem values?

\section{Methods}

\subsection{Study locations and context}

Two PPGIS case study areas in Norway were selected that provide a contrast in both physical landscape character and land tenure (Hausner et al., in press). The southern study area, located in the Sogn region, is characterized by fjords stretching $200 \mathrm{~km}$ through glaciers and mountain plateaus and includes more than 10 of the highest peaks in Norway. We included six municipalities along this fjord belonging to the counties of Sogn og Fjordane and the mountain plateau in Oppland covering a total of $15,862 \mathrm{~km}^{2}$. Less than $5 \%$ of the study area is used for cultivation or forestry with about half of the properties in the region being less than one ha in size (Mathiesen et al., 2013). In the valley of Sogn, most of the land is privately owned, while land located on mountain plateaus is almost entirely covered by village or state commons with local usufruct rights to grazing, hunting, fishing, and tourism income. The main economic activities are livestock grazing, tourism, and hydroelectric power, while lowland areas are more diverse and include cruise tourism, aquaculture, and fruit and berry cultivation. Villages are generally small, but there two major hubs in Sogn, Voss and Sogndal with 14,006 and 7,623 inhabitants respectively. There are four national parks located in the study region (Breheimen, Jotunheimen, Reinheimen, Jostedalsbreen) mostly situated in the uplands and there are two large protected landscapes, Stølsheimen and Nærøyfjorden. 
The Nordland region is characterized by a narrow coastline with connection to the open sea, with several small fjords and sharp peaks in the west. The area covers six municipalities in the county of Nordland. The total area is $8,337 \mathrm{~km}^{2}$ with $52 \%$ owned by the state through the state-owned company Statsskog SF. This state property differs from state commons land as it does not have user rights extending beyond the right of common access for locals, but Sami reindeer herders have usufruct rights to grazing and other traditional uses. The alpine areas in the region are especially important for reindeer husbandry, as these areas are often lichen-rich, good pasture for reindeer. The municipalities of Bodø and Fauske have about 50,000 and 9,000 inhabitants respectively but the remainder of the study area has a small, rural population with a high proportion employed in the primary industries. There are five national parks in the study region: Rago, Sjunkhatten, Junkerdal, Saltfjellet-Svartisen, and Lahko, and five protected landscape areas.

\section{[Insert Figure 1]}

\subsection{Data collection and sampling}

The research team designed, pre-tested, and implemented two internet-based PPGIS websites (Nordland and Sogn) in Norwegian language for data collection. The websites consisted of an opening screen for participants to either enter or request an access code, followed by an informed consent screen for participation, and then a Google ${ }^{\circledR}$ maps interface where participants could drag and drop digital markers onto a map of the study area. The mapping interface consisted of a "tab" panel containing markers with 14 ecosystem values plus a marker to identify the location(s) of cabins or summer farms (see definitions in Table 2). The selection of ecosystem values to be mapped was based on a values typology first developed by Brown and Reed (2000) for participatory mapping in Alaska. The typology was modified and adapted for use in Norway based on consultation with protected area managers in the two study areas.

The instructions requested that participants drag and drop the markers onto map locations that are important for the values listed. The different types of markers and their spatial locations were recorded for each participant on a web server in a database, along with other information including a timestamp of when the marker was placed, the Google ${ }^{\circledR}$ map view, and the Google ${ }^{\circledR}$ map zoom level (scale) at which the marker was placed. Participants could place as few or as many markers as they deemed necessary to identify ecosystem values. Following completion of the mapping activity (placing 

assess socio-demographic characteristics.

\section{[Insert Table 2]}

Household sampling was used in both the Nordland and Sogn study areas to recruit study participants. In Sogn, the municipalities of Voss, Sogndal, Luster, Skjåk, Våga, Aurdal were sampled and $10 \%$ of the adult population (>18 years) were randomly drawn for a potential 3,104 participants. Selected individuals were sent a letter of invitation and a reminder two weeks after the initial invitation. Parallel to household recruitment, we contacted a number of regional organizations ( $n=274)$, either by email or Facebook, to inform them about the study and to encourage volunteer participation.

In Nordland, households in the municipalities of Bodø, Fauske, Saltdal, Gildeskål, Sørfold and Beiarn were randomly sampled for a potential 3,054 participants. A total of 216 organizations were also contacted for potential volunteer participation through email or social media.

\subsection{Analyses}

\subsubsection{Participant characteristics}

We assessed the representativeness of participants in both study areas with Norwegian census data on the variables of age, gender, education, income, and family structure. We also examined the geographic distribution of participants within the study areas based on postcode provided.

\subsubsection{Data preparation}

The global land cover GIS layer used in this study was developed by the European Space Agency in collaboration with the Université Catholique de Louvain (Bontemps et al., 2011). The land cover map has a spatial resolution of $300 \mathrm{~m}$ with 22 land cover classes. The overall accuracy weighted by the class area was $67.5 \%$ using 2,190 globally distributed points, including homogeneous and heterogeneous landscapes (Bontemps et al., 2011, p. 47). The global land cover layer was clipped to the boundaries of the Nordland and Sogn study areas and spatially intersected with the mapped ecosystem value points. Thus, each mapped ecosystem value had an associated land cover class.

To perform ecosystem service bundle analysis, a $2 \mathrm{~km}$ vector grid (a.k.a. fishnet) was overlaid with each study area. This grid size was chosen as a heuristic to achieve the highest possible resolution 
but with the fewest number of empty grid cells. The number and type of mapped points were tabulated in each grid cell. The proportion of each land cover class was also tabulated within each grid cell.

\subsubsection{Data analysis - relationship between ecosystems values and land cover}

We assessed the relationship between ecosystem values and land cover in each study area using multiple methods. In the first analysis, we generated cross-tabulations, chi-square statistics, and standardized residuals to examine the distribution of mapped ecosystem values by land cover class. The chi-square test for independence was applied between the categorical variables of ecosystem value type and land cover class to determine whether there was a significant association between the variables. Standardized residuals were calculated to determine whether the number of mapped points differed significantly from the expected number of points in each land cover class. Expected counts are the projected point frequencies in each land cover class if the null hypothesis is true, i.e., if there is no association between ecosystem values and land cover class. This type of analysis does not account for the areal distribution of land cover classes within the study area.

In the second analysis, land cover area was considered and expected counts were calculated under the assumption that mapped point distributions in each land cover class should be proportional to the area occupied by the land cover class. For example, if a land cover class occupies 60 percent of a study area, 60 percent of the total mapped points would be expected to fall within this land cover class. To determine whether specific mapped values were proportionately distributed within land cover classes, $\mathrm{Z}$ scores were calculated for each value/land cover pair as follows:

$$
Z=\frac{\mathrm{Ps}-\mathrm{P} \mu}{S p}
$$

where: $\mathrm{P}_{\mathrm{S}}=$ sample proportion (proportion of value points within a land cover class)

$\mathrm{P}_{\mu}=$ population proportion (proportion of study area occupied by the land cover class) $\mathrm{S}_{\mathrm{p}}=$ standard error of the population

$\mathrm{Z}$ scores greater than +1.96 (two-tailed test, $\alpha=.05$ ) indicate that the proportion of value points falling within a given land cover class are significantly greater than expected, while $\mathrm{Z}$ scores less than -1.96 indicate the proportion of value points are significantly less than expected. 


\subsubsection{Assessment of spatial "bundles" of ecosystem services}

To determine whether ecosystem values were mapped in spatial "bundles", we overlaid the Nordland and Sogn study areas with a two kilometer vector grid resulting in $n=2,970$ grid cells (Nordland) and $n=4,544$ grid cells (Sogn). The ecosystem values by marker type $(n=14)$ were tabulated in each grid cell. The two data sets were then combined and all grid cells containing one or more ecosystem values were retained for analysis resulting in $n=3030$ grid cells. The grid cell counts for the ecosystem values were then factor analyzed (SPSS v.22) using principal components extraction with the number of extracted factors determined by eigenvalues greater than one (Kaiser, 1960). The resulting factors were rotated using varimax rotation to enhance interpretation. Factor scores for each grid cell were generated using regression and Spearman rank correlations were calculated between the factor scores and the proportion of land cover class located in each grid cell. This correlational analysis provides an indicator of whether ecosystem value bundles are related (or not) to land cover classes.

\subsubsection{Demonstrating value transfer methods based on land cover spatial associations}

The final analysis was to demonstrate and evaluate the results of value transfer methods between the two study areas using the land cover spatial associations derived from previous analyses. This study represents a "best case" scenario for demonstrating value transfer methods because of the similarity in land cover classes in the two study areas and the social and cultural characteristics of the two populations sampled. Recreation value was selected for the purpose of value transfer analysis because it was the most frequently mapped ecosystem value in both the Nordland and Sogn study areas, thus providing the best opportunity to identify and quantify spatial associations for the purpose of value transfer. The Sogn study area was selected to benchmark "actual" versus "value transfer" spatial distributions using indices derived from: (1) recreation value proportions within each land cover class, (2) deviations from expected recreation counts with land cover classes (chi-square residuals), and (3) Spearman correlation coefficients between land cover classes and ecosystem bundles containing recreation values. These value transfer indices were selected to provide contrast in the range of possible quantitative methods for value transfer mapping. Spatial association indices were generated using recreation value distributions in Nordland and then applied to render recreation value distributions in Sogn. The percent (proportion) of mapped recreation values in each land cover class is the simplest of value transfer indices. This method assumes that recreation values would be similarly distributed across land cover classes where primary data was not collected. The use of chi-square standardized residuals 
as indices assumes that deviations of mapped ecosystem values from expected counts reflect the relative importance of the ecosystem value between different land cover classes. The use of correlation coefficients between ecosystem bundles containing the ecosystem value of interest and land cover assumes that ecosystem values are best understood as spatially associated groups of values rather than individual values.

Maps showing the spatial distribution of recreation values by land cover class in Sogn were generated from (1) the Sogn mapped data, and (2) transfer indices derived from empirical spatial associations found in Nordland (see Table 6). The maps were generated by applying the proportion, residual, and correlation values associated with each land cover class in Nordland to the same land cover class in Sogn. To visually compare the results, the same defined intervals of transfer indices and color ramps were applied to the two maps (actual vs. value transfer). The similarity or contrast in map color provides a qualitative indicator of the error involved when using a particular value transfer method.

The similarity between the actual and value transfer maps was quantified by calculating product-moment correlations between the actual and transfer values associated with each land cover cell $(300 \mathrm{~m})$ in Sogn $(n=345,351)$. This aggregate measure of map similarity accounts for the similarity between the actual and transfer index values in each land cover class as shown in Table 6 (similar actual and transfer values increase the map correlation coefficient) and the proportion of the study region contained in the land cover class (similar actual and transfer values in the largest land cover classes increase the map correlation coefficient).

\section{Results}

\subsection{Study Response and participant characteristics}

A total of 440 and 486 participants accessed the Sogn and Nordland study websites respectively, placing one or more markers from November 2014 to January 1, 2015. See Table 3. The response profiles for the two study areas were similar. The estimated response rates, after accounting for non-deliverable letters of invitation, was 14 percent in Sogn and 16.3 percent in Nordland. A total of 19,134 markers were mapped across both study areas wherein $64 \%$ of the markers placed were ecosystem value markers used in this analysis. 


\section{[Insert Table 3]}

Most participants (approximately 90\%) learned of the study directly through a recruitment letter from the Arctic University of Norway. Referrals to the study website were encouraged and an estimated $10 \%$ of participants learned of the study indirectly from friends, organizations, or social media. Table 3 also provides a socio-demographic profile of study participants with comparative Norway census data derived from Statistics Norway (2013). The mean age of participants was 49 years, with more males, higher levels of formal education, and higher self-reported household income than comparable Norwegian census data. About half of the participants were from families with children. The PPGIS participation bias toward more highly educated and higher income males is consistent with other reported PPGIS studies in developed countries (Brown and Kyttä, 2014). We also assessed the geographic distribution of participants by plotting the number of participants by their post code. See Figure 1.

\subsection{Relationships between ecosystem values and land cover}

Norway's land cover classes comprise a smaller subset of the 22 possible land cover classes identified in the global land cover database (Bontemps et al., 2011). Each class is identified with a unique numeric code and land cover description. For example, class 50 is "closed broad-leaved deciduous forest" while class 220 is "permanent snow and ice". Tables 5 and 6 provide the land cover descriptors associated with each unique code used in the analysis. Figure 2 shows terrestrial global land cover by class compared to land cover in the two Norway study areas, and the percent of total ecosystem values mapped in each land cover class. Land cover in the two study areas is dominated by forests, sparse vegetation, and bare areas with little land in agriculture, grassland, or developed area classes. In the forest cover classes, mapped value proportions exceed areal proportions, but ecosystem values were under-represented in the "bare" class. The differences in proportions were assessed for statistical significance with results reported in Figures 3 and 4. Statistical significance $(p \leq 0.05)$ is shown by $z$ score bars extending beyond +1.96 (over-represented) and less than -1.96 (underrepresented).

\section{[Insert Figure 2]}




\section{[Insert Figure 3 and Figure 4]}

The analysis of ecosystem values by land cover using chi-square residuals provides a different approach to assessing relationships because it does not assume that ecosystem values should be distributed proportional to land cover area. Residuals reflect mapped participant associations of ecosystem values with land cover without regard to the actual proportion of land cover. The chi-square residuals results are presented in Figures 5 and 6. Similar to the proportional analysis, there were more significant value/land cover results in Nordland ( 25 over/24 under) than Sogn (6 over/5 under). Residuals analysis also shows greater variability in ecosystem value distributions within a given land cover class as evidenced by the contrast in positive and negative residual scores. Every land cover class had at least one statistically significant association with an ecosystem value. Many of the residual results were similar to the proportional results based on the directionality of the association (above or below 0), but there were some exceptions. For example, scenic values had positive z scores in all forest classes in proportional analysis, but the residuals were negative in closed broad-leaved forests (Class 50) and open mixed forest (Class 100). Similarly, naturalness values had positive proportionality z scores for all forest classes, but statistically significant negative residuals for closed broad-leaved forests (Class 50), open needle-leaved (Class 90), and mixed forest/shrubland (Class 110). Higher than expected mapping of clean water and fishing values in water bodies (Class 210) emerged as significant, while mapped special places were higher than expected in areas of permanent snow and ice (Class 220). Spiritual and natural values were also significantly higher than expected in bare areas (Class 200) using residuals analysis.

\section{[Insert Figure 5 and Figure 6]}




\subsection{Ecosystem bundles and relationship to land cover}

To determine whether ecosystem values were mapped in spatial "bundles", we performed factor analysis on the quantities of ecosystem values found within two kilometer grid cells across the two study regions. The results of the factor analysis appear in Table 4. Four factors were extracted from the 14 values that account for 52 percent of the overall variance. The values that load on the first factor and capture 32 percent of the variance are items that relate to the concept of place attachment as described by Williams and Vaske (2003) consisting of the two dimensions of place identity and place dependence. The place attachment construct is closely related to the cultural ecosystem service identified in the MEA report (2005) called "sense of place". Place identity refers to the mixture of feelings about specific physical settings and symbolic connections to place that define who we are, while place dependence is the functional or goal-directed relationship to the setting and the extent to which the setting supports intended uses. The mapped income value appears indicative of place dependence (i.e., the place is functional because it provides a source of income) while cultural identity and spiritual values appear indicative of place identity (i.e., the place is a source for emotions and relationships that give meaning to life). The loading of "special places" on this factor is also consistent with interpretation of this factor as Brown and Raymond (2007) found mapped special places to be significantly related to place identity and dependence constructs. The other three factors suggest ecosystem bundles representing recreation values with social and therapeutic co-benefits ( 3 items, $10 \%$ of variance), natural landscape bundles (4 items, $8 \%$ of variance) where scenery, biodiversity, clean water, and undisturbed nature co-locate, and provisioning bundles ( 3 items, $7 \%$ of variance) that provide opportunities for hunting/fishing, gathering, or forage for domestic animals.

\section{[Insert Table 4]}




\section{[Insert Table 6] [Insert Figure 7]}

When the spatial distribution of recreation values in Sogn were generated from the proportion of recreation values mapped in land cover classes in Nordland, the value transfer distribution was quite similar to the actual distribution (Figure 7a). The overall measure of map similarity was high $(\mathrm{r}=0.98, \mathrm{p}$ $<0.001)$ and resulted from relatively small differences in recreation value proportions associated with the different land cover classes in the two study areas. When standardized residuals were used to transfer spatial associations found in Nordland to Sogn, large and visually significant differences were visible (Figure 7b) with overall map similarity small and negative ( $\mathrm{r}=-0.07, \mathrm{p}<0.001)$. The low map similarity resulted from study participants in the two regions expressing different relative quantities of recreation values with land cover, especially in the forest cover land classes (i.e., Classes $50-120$ ). 


\section{Discussion}

This study assessed the spatial relationships between participatory mapped ecosystem values and land cover in two study regions in Norway. The Norwegian landscape, while topographically dramatic, is not diverse in land cover and is dominated by sparse or bare vegetation in the uplands, and mixed forests in the lower elevations. The spatial associations of ecosystem values with land cover were consistent with findings reported in other studies (Brown, 2013), with forested areas providing multiple ecosystem bundles supporting both recreation-related and provisioning values. The Norwegian uplands are valued for their relatively undisturbed character and scenery, but local identity and place attachment have stronger association with forested and settled areas in proximity to water bodies. Sense of place (place attachment), a cultural ecosystem service identified in the MEA report (2005), emerged as a distinctive ecosystem bundle in this Norwegian context

What are the implications of the spatial associations reported herein? A common theme identified in the ecosystem services literature is the need to better integrate ecosystem values into land use planning and decision support (De Groot et al., 2010; Opdam, 2013), but the formal assessment of cultural ecosystem services with primary data collection is relatively rare. In the absence of primary data, the ability to identify the distribution of ecosystem values from secondary or proxy data for planning decision support has significant appeal. Spatial associations with physical landscape characteristics, if valid, can be used to "value transfer" or extrapolate ecosystem values to areas or regions where no primary data exists. And yet, as Eigenbrod et al., (2010a) caution, generalization 
errors in the value transfer process can be sufficiently large so as to undermine decisions based on extrapolated maps. Generalization error can be subdivided into three components of uniformity, sampling, and regionalization (Plummer, 2009). Uniformity error occurs when ecosystem values are not constant (uniform) for a particular land cover, sampling error results from too few study areas to develop transfer indices or coefficients, and regionalization error occurs when the study area is not representative of the area being transfer mapped. Although these generalization errors have been assessed for biophysical indicators of ecosystem services, these errors appear equally applicable to value transfer processes that use participatory mapped data.

How do these errors relate to the value transfer analysis in this study? In the value transfer of recreation values to Sogn using Nordland spatial associations, there was an assumption that recreation value distributions were uniform within each of the land cover classes, for example, Class 150 (sparse vegetation). This was clearly not the case as evidenced by the clustering of recreation value points at specific locations within the land cover class. Further, cultural ecosystem values appear especially susceptible to uniformity errors because cultural values tend to be place-specific and clustered on the landscape. As noted by Eigenbrod et al., (2010b), uniformity error alone can make ecosystem service maps generated through the transfer process unsuitable for identifying hotspots or priority areas for multiple services.

With respect to sampling error, the sample size of one (i.e., Nordland) used to generate transfer indices for Sogn suggests a very large sampling error. Ideally, multiple participatory mapping studies would be conducted throughout Norway to increase confidence that the spatial associations of ecosystem values with land cover in Nordland are not unique or indicative of outliers. Regionalization error is also a distinct possibility within Norway because although the physical landscapes in the two study areas were reasonably similar, there are significant differences in land tenure between Nordland and Sogn with empirical evidence indicating that land tenure influences the distribution of ecosystem values (Hausner et al., in press). The sparse land cover class in the mountains includes areas that are locally important for recreational fishing, naturalness, and scenic qualities. Social and therapeutic values were typically mapped near settlements, particularly in the more urbanized locations in Nordland, reflecting the importance of green infrastructure connected to recreational and ski trails.

The value transfer process using ecosystem bundle correlation coefficients showed poor performance with low similarity $(r=.35)$ between the actual and value transfer maps. The use of ecosystem bundles to generate singular transfer indices is subject to the same type of error in 
aggregation identified by Eigenbrod et al. (2010a) who found that combining multiple ecosystem services into a single layer for benefit transfer is problematic because it contains errors for each constituent layer. The generalization and aggregation errors in the value transfer mapping process are layered on the top of error that is intrinsic to the participatory mapping process itself, such as value construct validity, sampling error, and spatial accuracy. Although empirical research to date indicates that participatory mapping of ecosystem values can generate reasonably accurate outcomes for some types of ecosystem values (Brown et al., 2014; Cox et al., 2014), a common characteristic of participatory mapping for ecosystem values is the use of regional case studies where external validity is intrinsically weak, constraining generalization outside the study area (Brown and Fagerholm, 2015).

Given the high probably of error in generating transfer maps that may not be reliable for decision support in land use planning, is the pursuit of more accurate value transfer methods misguided effort? Not necessarily, but a fair degree of skepticism is warranted. Eigenbrod et al., (2010a) describe the limited range of circumstances where transfer mapping may be suitable: (1) when the heterogeneity of ecosystem services within a land cover type is low, such as in smaller study areas; and (2) if the goal of transfer mapping is simply to rank the relative importance of a small number of highly distinct land cover types in terms of their importance for one or more ecosystem services. The use of land cover data for value transfer is understandable given its availability, but it is possible to enhance value transfer mapping methods using additional physical landscape data layers. Value transfer mapping that includes more extensive physical landscape features such as those in the New Zealand landscape classification system (i.e., land cover, dominant land cover, landform, water bodies, water views, and infrastructure (Brabyn, 2009) have the potential to improve value transfer accuracy for some ecosystem values. This type of comprehensive, hierarchical landscape classification system was not available for Norway, but it could be developed in the future.

As a caveat, even with more accurate value transfer mapping, the results may not be adequate for land use decision support when confronted with high variability in the social systems that drive the valuation process. Although mapped ecosystem values in rural regions appear to be relatively stable over time (Brown and Donovan, 2014; Brown and Weber, 2012), cultural ecosystem values, in particular, have the potential to couple or decouple with physical landscape features. But given the paucity of research that has examined spatial associations between mapped ecosystem values and physical landscapes, it would be premature to dismiss the potential utility of value transfer mapping without further effort to identify and calibrate the spatial associations. We concur with Eigenbrod et al., 
(2010a) that at this point in time, available resources may be better invested to map the actual distribution of ecosystem services than in value transfer methods per se. A direct benefit of new empirical data collection would be to increase the knowledge base of spatial associations between mapped ecosystem values and physical landscapes which at the present, is limited in geographic scope and socio-cultural coverage. Further, the P(P)GIS mapping of ecosystem services that are relevant to indigenous and local people living in sparsely populated and data poor regions may be the most viable option to identify and model the spatial distribution of ecosystem values (Ramirez-Gomez, 2015). Value transfer mapping can be revisited in the future with an expanded knowledge base to determine its utility for land use decision support.

\subsection{Conclusion}

This study identified the empirical spatial associations between physical landscape features (land cover) and mapped ecosystem values, and then used the results to evaluate value transfer outcomes. The study affirmed spatial associations described elsewhere, for example, the importance of forested landscapes that provide a wide range of both cultural and provisioning ecosystem services. However, the capacity to extrapolate or transfer spatial associations from one geographic location to another depends on the validity and comprehensiveness of physical landscape descriptors (e.g., land cover), the validity of ecosystem value descriptors (e.g., ecosystem value types), and the ability to operationalize and accurately measure these components.

The initial SolVES model (Sherrouse et al., 2011) used landscape features such as roads, water, and elevation as the basis for value transfer. These landscape descriptors appear too general for the purpose of value transfer. An alternative approach, described herein, uses a landscape classification system such as land cover as the basis for value transfer. Although land cover is an improvement over general landscape features, land cover may also be too general to capture the complexity of physical landscapes in sufficient detail for the purpose of value transfer. A more promising approach would use comprehensive and detailed landscape classification systems such as those developed by Brabyn (2009) for New Zealand or landscape character systems developed by Käyhkö (2015) for Zanzibar, Tanzania. Unfortunately, comprehensive landscape classification systems require considerable effort to develop and validate and thus are not widely available. For the ecosystem valuation component, the participatory mapping of ecosystem values is relatively new and underdeveloped (Brown and Fagerholm, 2015) and like physical landscape descriptors, lacks sufficient specificity to capture the 
complexity of the human valuation process across heterogeneous populations. Progress in value transfer methods will depend on enhanced classification and valuation systems that better capture and measure the complexity of both physical landscapes and the human valuation process.

With the relatively homogenous physical landscape and culture found in Norway compared to other global geographic locations, this case study presented a best case scenario to demonstrate the viability of value transfer methods. While the use of standardized residuals and ecosystem value bundles for value transfer did not perform well, the use of simple percentages describing ecosystem value/land cover spatial associations generated reasonably strong results (i.e., high similarity between actual and value transfer maps). While we share the multiple concerns expressed by Eigenbrod et al., (2010b) regarding the validity of value transfer methods for ecosystem services, our empirical results have left open the possibility that value transfer methods can be useful for some applications in the future including the spatial identification of cultural ecosystem values. 


\section{References}

Alessa, L.N., Kliskey, A.A., Brown, G., 2008. Social-ecological hotspots mapping: A spatial approach for identifying coupled social-ecological space. Landscape and Urban Planning 85, 27-39.

Bagstad, K. J., Reed, J. M., Semmens, D. J., Sherrouse, B. C., Troy, A. 2015. Linking biophysical models and public preferences for ecosystem service assessments: a case study for the Southern Rocky Mountains. Regional Environmental Change, 1-14.

Berkes, F., Colding, J., Folke, C. (Eds.). 2002. Navigating social-ecological systems: building resilience for complexity and change. Cambridge University Press. 416 p.

Bontemps, S., Defourny, P., Van Bogaert, E., Arino, O., Kalogirou, V., Ramos Perez, J. 2011. GLOBCOVER 2009-Products description and validation report. Available from < http://due.esrin.esa.int/files/GLOBCOVER2009_Validation_Report_2.2.pdf > Accessed (13 July 2015).

Brabyn, L. 2009. Classifying landscape character. Landscape research, 34(3), 299-321.

Brown, G., 2013. The relationship between social values for ecosystem services and global land cover: An empirical analysis. Ecosystem Services 5, 58-68.

Brown, G., Montag, J.M., Lyon, K., 2012. Public participation GIS: A method for identifying ecosystem services. Society \& Natural Resources 25, 633-651.

Brown, G., Raymond, C. 2007. The relationship between place attachment and landscape values: Toward mapping place attachment. Applied Geography. 27(2):89-111.

Brown, G., Weber, D., de Bie, K., 2014. Assessing the value of public lands using public participation GIS (PPGIS) and social landscape metrics. Applied Geography 53, 77-89.

Brown, G., 2005. Mapping spatial attributes in survey research for natural resource management: Methods and applications. Society \& Natural Resources 18, 17-39.

Brown, G., Brabyn, L., 2012a. The extrapolation of social landscape values to a national level in New Zealand using landscape character classification. Applied Geography 35, 84-94.

Brown, G., Brabyn, L., 2012b. An analysis of the relationships between multiple values and physical landscapes at a regional scale using public participation GIS and landscape character classification. Landscape and Urban Planning 107, 317-331.

Brown, G. and Fagerholm, N. 2015. Empirical PPGIS/PGIS mapping of ecosystem services: A review and evaluation. Ecosystem Services 13, 119-133.

Brown, G., Kyttä, M., 2014. Key issues and research priorities for public participation GIS (PPGIS): A synthesis based on empirical research. Applied Geography 46, 122-136. 
Brown, G., Reed, P. 2000. Validation of a forest values typology for use in national forest planning. Forest Science 46(2), 240-247.

Brown, G., Weber, D. 2012. Using Public Participation GIS (PPGIS) on the Geoweb to monitor tourism development preferences. Journal of Sustainable Tourism 21(2), 192-211.

Bryan, B.A., Raymond, C.M., Crossman, N.D., Macdonald, D.H., 2010. Targeting the management of ecosystem services based on social values: Where, what, and how? Landscape and Urban Planning 97, 111-122.

Clement-Potter, J. 2006. Spatially explicit values on the Pike and San Isabel national forests in Colorado (Ph.D. thesis). Fort Collins, CO: Colorado State University.

Costanza, R., R. d'Arge, R. de Groot, S. Farberk, M. Grasso, B. Hannon, K. Limburg, S. Naeem, R. O’Neill, J. Paruelo, R. Raskin, P. Suttonkk, and M. van den Belt. 1997. The value of the world's ecosystem services and natural capital. Nature 387:253-260.

Daily, G. 1997. Nature's services: Societal dependence on natural ecosystems. Island Press.

Daniel, T.C., Muhar, A., Arnberger, A., Aznar, O., Boyd, J.W., Chan, K.M.A., Costanza, R., Elmqvist, T., Flint, C.G., Gobster, P.H., Grêt-Regamey, A., Lave, R., Muhar, S., Penker, M., Ribe, R.G., Schauppenlehner, T., Sikor, T., Soloviy, I., Spierenburg, M., Taczanowska, K., Tam, J., von der Dunk, A., 2012. Contributions of cultural services to the ecosystem services agenda. PNAS, 1-8.

De Groot, R. S., Wilson, M. A., Boumans, R. M. 2002. A typology for the classification, description and valuation of ecosystem functions, goods and services. Ecological economics, 41(3), 393-408.

De Groot, R. S., Alkemade, R., Braat, L., Hein, L., Willemen, L. 2010. Challenges in integrating the concept of ecosystem services and values in landscape planning, management and decision making. Ecological Complexity, 7(3), 260-272.

Eigenbrod, F., Armsworth, P. R., Anderson, B. J., Heinemeyer, A., Gillings, S., Roy, D. B., et al. 2010a. Error propagation associated with benefits transfer-based mapping of ecosystem services. Biological Conservation, 143(11), 2487-2493. http://dx.doi.org/10.1016/j.biocon.2010.06.015

Eigenbrod, F., Armsworth, P.R., Anderson, B.J., Heinemeyer, A., Gillings, S., Roy, D.B., Thomas, C.D., Gaston, K.J., 2010b. The impact of proxy-based methods on mapping the distribution of ecosystem services. Journal of Applied Ecology 47, 377-385.

Fagerholm, N., Käyhkö, N., Ndumbaro, F., Khamis, M., 2012. Community stakeholders' knowledge in landscape assessments - Mapping indicators for landscape services. Ecological Indicators 18, 421-433.

Fisher, B., Turner, R. K., Morling, P. 2009. Defining and classifying ecosystem services for decision making. Ecological Economics, 68(3), 643-653. 
Goodchild, M. F. 2007. Citizens as sensors: the world of volunteered geography. GeoJournal, 69(4), 211-221.

Haines-Young, R. and Potschin, M. 2013. Common International Classification of Ecosystem Services (CICES): Consultation on Version 4, August-December 2012. EEA Framework Contract No EEA/IEA/09/003.

Hausner, V., Brown, G., and Lægreid, E. In press. Effects of land tenure and protected areas on ecosystem services and land use preferences in Norway. Land Use Policy.

Kaiser, H. F. 1960. The application of electronic computers to factor analysis. Educational and psychological measurement. 20, 141-151.

Käyhkö, N. 2015. Participatory landscape character assessment (LCA) for land use planning and forest management in Zanzibar, Tanzania. Paper presented at the International Association for Landscape Ecology (IALE) Congress, July 5-10, Portland, Oregon. Abstract retrieved from http://ialeworldcongressabstracts.org/presentation.php?author_last=Kayhko\&author_first=Niina

Klain, S.C., Chan, K.M.A., 2012. Navigating coastal values: Participatory mapping of ecosystem services for spatial planning. Ecological Economics 82, 104-113.

Kumar, P. 2010. The economics of ecosystems and biodiversity: Ecological and economic foundations. UNEP/Earthprint.

Martín-López B, Iniesta-Arandia I, García-Llorente M, Palomo I, Casado-Arzuaga I, et al. 2012. Uncovering Ecosystem Service Bundles through Social Preferences. PLoS ONE 7(6): e38970.

Mathiesen, H., Tenge, I., Lågbu, R., Snellingen Bye, A., 2013. Arealstatistikk: Eiendommer og Utmark. Norsk Institute for Skog og Landskap. Available from: http://www.skogoglandskap.no/filearchive/rapport_21_13_arealstatistikk_eiendommer_og_utmar k.pdf (accessed 13.02.15).

MEA (Millennium Ecosystem Assesment), 2005. Ecosystems and Human Well-being: A Framework for Assessment. Island Press, Washington D.C.

National Center for Geographic Information and Analysis (NCGIA). 1996a. Summary report: GIS and society workshop, South Haven, MN, 2-5 March. FFF. 1996 b.

National Center for Geographic Information and Analysis (NCGIA). 1996a. Summary report: Public participation GIS workshop, Orono, ME, 10-13 July.

Obermeyer, N.J. 1998. The evolution of public participation GIS. Cartography and Geographic Information Systems, 25(2), 65-66. 
Opdam, P., 2013. Using ecosystem services in community-based landscape planning: Science is not ready to deliver, in Fu, B., Jones, K.B. (Eds.), Landscape Ecology for Sustainable Environment and Culture. Springer Netherlands, pp. 77-101.

Palomo, I., Martín-López, B., Potschin, M., Haines-Young, R., Montes, C., 2013. National Parks, buffer zones and surrounding lands: Mapping ecosystem service flows. Ecosystem Services 4, 104-116.

Palomo, I., Martín-López, B., Zorrilla-Miras, P., Del Amo, D.G., Montes, C. 2014. Deliberative mapping of ecosystem services within and around Doñana National Park (SW Spain) in relation to land use change. Regional Environmental Change, 14(1), 237-251.

Plieninger, T., Dijks, S., Oteros-Rozas, E., Bieling, C., 2013. Assessing, mapping, and quantifying cultural ecosystem services at community level. Land Use Policy 33, 118-129.

Plummer, M.L. 2009. Assessing benefit transfer for the valuation of ecosystem services. Frontiers in Ecology and the Environment, 7, 38-45

Potschin, M., Haines-Young, R., 2013. Landscapes, sustainability and the place-based analysis of ecosystem services. Landscape Ecology 28, 1053-1065.

Queiroz, C., Meacham, M., Richter, K., Norström, A.V., Andersson, E., Norberg, J., Peterson, G. 2015. Mapping bundles of ecosystem services reveals distinct types of multifunctionality within a Swedish landscape. Ambio 44, 89-101.

Rambaldi, G., Kwaku Kyem, A.P., Mbile, P., McCall, M.,Weiner, D. 2006. Participatory spatial information management and communication in developing countries. EJISDC, 25, 1.

Ramirez-Gomez S.O.I., Torres-Vitolas, C.A., Schreckenberg, K., Honzák, M, Cruz-Garcia, G.S., Willcock, S., Palacios, E.,Pérez-Miñana, E, Verweij, P.A., Poppy, G.M. 2015. Analysis of ecosystem services provision in the Colombian Amazon using participatory research and mapping techniques. Ecosystem Services 13, 93-107.

Raudsepp-Hearne, C., Peterson, G.D., Bennett, E.M., 2010. Ecosystem service bundles for analyzing tradeoffs in diverse landscapes. PNAS 107, 5242-5247.

Raymond, C. M., Bryan, B. A., MacDonald, D. H., Cast, A., Strathearn, S., Grandgirard, A., Kalivas, T. 2009. Mapping community values for natural capital and ecosystem services. Ecological economics, 68(5), 1301-1315.

Raymond, C., Brown, G., 2007. A spatial method for assessing resident and visitor attitudes towards tourism growth and development. Journal of Sustainable Tourism 15, 520-540.

Troy, A., Wilson, M. A. 2006. Mapping ecosystem services: practical challenges and opportunities in linking GIS and value transfer. Ecological Economics, 60(2), 435-449. 
van Riper, C.J., Kyle, G.T., Sutton, S.G., Barnes, M., Sherrouse, B.C., 2012. Mapping outdoor recreationists' perceived social values for ecosystem services at Hinchinbrook Island National Park, Australia. Applied Geography 35, 164-173.

van Riper, C.J., Kyle, G.T., 2014. Capturing multiple values of ecosystem services shaped by environmental worldviews: A spatial analysis. Journal of Environmental Management 145, 374384.

Shannon, C.E., 1948. A mathematical theory of communication. The Bell System Technical Journal, 27, 379-423 and 623-656.

Sherrouse, B.C., Clement, J.M., Semmens, D.J., 2011. A GIS application for assessing, mapping, and quantifying the social values of ecosystem services. Applied Geography 31, 748-760.

Sherrouse, B.C., Semmens, D.J., Clement, J.M., 2014. An application of Social Values for Ecosystem Services (SolVES) to three national forests in Colorado and Wyoming. Ecological Indicators 36, 68-79.

Statistics Norway (2013). Population and housing census 2011. http://www.ssb.no

Turner, K.G., Odgaard, M.V., Bøcher, P.K., Dalgaard, T., Svenning, J.C. 2014. Bundling ecosystem services in Denmark: Trade-offs and synergies in a cultural landscape. Landscape and Urban Planning, 125, 89-104.

Wallace, K.J. 2007. Classification of ecosystem services: problems and solutions. Biological Conservation, 139(3), 235-246.

Williams, D.R., Vaske, J.J. 2003. The measurement of place attachment: Validity and generalizability of a psychometric approach. Forest Science, 49(6), 830-840.

Zhu, X., Pfueller, S., Whitelaw, P., Winter, C., 2010. Spatial differentiation of landscape values in the Murray River Region of Victoria, Australia. Environmental Management 45, 896-911. 
Table 1. Participatory mapping studies that examined relationships between mapped cultural ecosystem values and physical landscape features.

\begin{tabular}{|c|c|c|c|c|c|c|c|c|}
\hline $\begin{array}{l}\text { Study } \\
\text { Year }^{\text {a }}\end{array}$ & Location & $\begin{array}{l}\text { Cultural ecosystem } \\
\text { values mapped }\end{array}$ & $\begin{array}{l}\text { Physical landscape } \\
\text { features }\end{array}$ & $\begin{array}{l}\text { Spatial } \\
\text { Mapping } \\
\text { Method }\end{array}$ & $\begin{array}{l}\text { Sampling method, } \\
\text { participants, data } \\
\text { collection method }\end{array}$ & Spatial Analyses & $\begin{array}{l}\text { Published } \\
\text { References }\end{array}$ & Selected relationships/findings \\
\hline 2013 & $\begin{array}{l}\text { Australia, New } \\
\text { Zealand, U.S. } \\
\text { (11 PPGIS } \\
\text { studies) }\end{array}$ & $\begin{array}{l}\text { Landscape value typology } \\
\text { ( } n=14 \text { values) }\end{array}$ & $\begin{array}{l}\text { Global land cover database } \\
\text { (Bontemps et al., 2011) }\end{array}$ & Points & Varied by study & $\begin{array}{l}\text { Point data tabulated within } \\
\text { land use areas to determine } \\
\text { spatial association between } \\
\text { ecosystem values and land } \\
\text { use categories }\end{array}$ & Brown, 2013 & $\begin{array}{l}\text { Highest frequencies associated with } \\
\text { forested land cover; water bodies highly } \\
\text { valuable relative to area occupied; } \\
\text { agricultural land and areas of permanent } \\
\text { snow and ice least valuable }\end{array}$ \\
\hline 2012 & $\begin{array}{l}\text { Channel } \\
\text { Islands, US }\end{array}$ & 12 landscape values & $\begin{array}{l}\text { Slope, land cover, distance to } \\
\text { infrastructure, distance to } \\
\text { marine protected areas, and } \\
\text { distance to coastline }\end{array}$ & Points & $\begin{array}{l}\text { Onsite visitors to Channel } \\
\text { Islands (survey) }(n=323)\end{array}$ & SolVES 2.0 model & $\begin{array}{l}\text { van Riper and Kyle, } \\
2014\end{array}$ & $\begin{array}{l}\text { Results for physical relationships not } \\
\text { reported }\end{array}$ \\
\hline 2012 & Saxony, DE & $\begin{array}{l}\text { Spiritual, educational, } \\
\text { inspiration, aesthetic, } \\
\text { social, sense of place, } \\
\text { cultural heritage, } \\
\text { recreation and ecotourism }\end{array}$ & $\begin{array}{l}\text { Land cover classes (forest, } \\
\text { cropland, grassland, water } \\
\text { body, settlement, and quarry) }\end{array}$ & $\begin{array}{l}\text { Assign } \\
\text { attributes to } \\
\text { pre-identified } \\
\text { sites on a } \\
\text { map }\end{array}$ & $\begin{array}{l}\text { Purposive resident } \\
\text { household (interviews) } \\
(\mathrm{n}=93)\end{array}$ & $\begin{array}{l}\text { Counts of services } \\
\text { identified/attached with land } \\
\text { cover classes }\end{array}$ & $\begin{array}{l}\text { Plieninger et al., } \\
2013\end{array}$ & $\begin{array}{l}\text { Recreation, aesthetics, and education } \\
\text { related to fishing ponds and lake; social } \\
\text { related to settlement; grasslands, } \\
\text { croplands, and quarry weakly related to } \\
\text { services }\end{array}$ \\
\hline 2011 & $\begin{array}{l}\text { Hinchinbrook } \\
\text { National Park, } \\
\text { Queensland, } \\
\text { AU }\end{array}$ & $\begin{array}{l}12 \text { landscape values but } \\
\text { only aesthetic, } \\
\text { biodiversity, and } \\
\text { recreation used in } \\
\text { analysis }\end{array}$ & $\begin{array}{l}\text { Slope, distance to water, } \\
\text { distance to trails }\end{array}$ & Points & $\begin{array}{l}\text { Onsite visitors (survey) } \\
(n=209)\end{array}$ & $\begin{array}{l}\text { SolVES } 1.0 \text { model analysis } \\
\text { by subgroup (consumptive } \\
\text { vs. non-consumptive) using } \\
\text { zonal statistics }\end{array}$ & $\begin{array}{l}\text { van Riper et al., } \\
2012\end{array}$ & $\begin{array}{l}\text { Consumptive subgroup aesthetic values } \\
\text { covered broader area spanning terrestrial } \\
\text { and aquatic environments (near water } \\
\text { and walking track) while non- } \\
\text { consumptive subgroup more intensely } \\
\text { valued a smaller area with steeper } \\
\text { slopes, close to trails, and farther from } \\
\text { bodies of water. }\end{array}$ \\
\hline 2011 & $\begin{array}{l}\text { Doñana and } \\
\text { Sierra Nevada } \\
\text { protected } \\
\text { areas, } \\
\text { Andalusia, ES }\end{array}$ & $\begin{array}{l}\text { MEA services customized } \\
\text { for each of two sites }\end{array}$ & Land use & Points & $\begin{array}{l}\text { Purposive expert } \\
\text { (workshops) }(\mathrm{n}=41)\end{array}$ & $\begin{array}{l}\text { Point data tabulated within } \\
\text { land use areas to determine } \\
\text { spatial association between } \\
\text { ecosystem services and } \\
\text { land use categories }\end{array}$ & Palomo et al., 2014 & $\begin{array}{l}\text { Land uses with highest richness of } \\
\text { ecosystem services were wetlands and } \\
\text { inland waters and shrublands. Urban } \\
\text { areas and agricultural lands had lowest } \\
\text { richness indicators. }\end{array}$ \\
\hline 2010 & $\begin{array}{l}\text { Grand County, } \\
\text { Colorado, US }\end{array}$ & Modified MEA typology & Land use/cover & Points & $\begin{array}{l}\text { Random household } \\
\text { (survey) }(n=58)\end{array}$ & $\begin{array}{l}\text { Point data tabulated within } \\
\text { land use/cover areas to } \\
\text { determine spatial } \\
\text { association between } \\
\text { ecosystem services and } \\
\text { land use/cover categories }\end{array}$ & Brown et al., 2012 & $\begin{array}{l}\text { Open water had proportionately } \\
\text { recreation values. Developed areas had } \\
\text { proportionately more social and cultural } \\
\text { service values. }\end{array}$ \\
\hline 2010 & $\begin{array}{l}\text { Cheju-Unguja } \\
\text { Ukuu Keabona, } \\
\text { Zanzibar, } \\
\text { Tanzania }\end{array}$ & $\begin{array}{l}\text { Landscape services } \\
\text { (material vs. non-material) }\end{array}$ & Land use/cover & Points & $\begin{array}{l}\text { Purposive resident } \\
\text { (interviews) }(n=218)\end{array}$ & $\begin{array}{l}\text { Distance of mapped } \\
\text { locations to home; spatial } \\
\text { overlay points with land } \\
\text { cover }\end{array}$ & $\begin{array}{l}\text { Fagerholm et al., } \\
2013\end{array}$ & $\begin{array}{l}\text { Material benefits cluster in the village } \\
\text { environments with majority of the } \\
\text { material assets found within a kilometer } \\
\text { distance from settlement on forest and } \\
\text { scrubland areas. Non-material benefits } \\
\text { also locate near settlement areas but } \\
\text { shared cultural traditions rarely co-exist } \\
\text { with other landscape benefits. }\end{array}$ \\
\hline 2011 & $\begin{array}{l}\text { Otago and } \\
\text { Southland } \\
\text { Regions, NZ }\end{array}$ & $\begin{array}{l}\text { Landscape values } \\
\text { typology }\end{array}$ & $\begin{array}{l}\text { Hierarchical land } \\
\text { classification system: } \\
\text { landform, land cover, water, } \\
\text { water views, and } \\
\text { infrastructure. }\end{array}$ & Points & $\begin{array}{l}\text { Random household, } \\
\text { onsite visitors, volunteer } \\
\text { (survey) }(n=608)\end{array}$ & $\begin{array}{l}\text { Point data tabulated within } \\
\text { land classes to determine } \\
\text { spatial association between } \\
\text { ecosystem services and } \\
\text { land use categories }\end{array}$ & $\begin{array}{l}\text { Brown and Brabyn, } \\
2012 a \text { and } 2012 b\end{array}$ & $\begin{array}{l}\text { Greater than expected landscape values } \\
\text { associated with urban areas, water } \\
\text { features, indigenous landcover, and } \\
\text { mountains. Fewer than expected values } \\
\text { associated with flatter, agricultural } \\
\text { landscapes }\end{array}$ \\
\hline 2008 & $\begin{array}{l}\text { Murray-Darling } \\
\text { Basin, South } \\
\text { Australia, AU }\end{array}$ & Modified MEA typology & $\begin{array}{l}\text { Four natural capital assets-- } \\
\text { land, water, biota, } \\
\text { atmosphere. }\end{array}$ & Points & $\begin{array}{l}\text { Non-proportional quota } \\
\text { decision-makers } \\
\text { (interviews) }(n=56)\end{array}$ & $\begin{array}{l}\text { Spatial distribution of } \\
\text { individual values were } \\
\text { summed (intensity) and }\end{array}$ & $\begin{array}{l}\text { Raymond et al., } \\
2009 ; \text { Bryan et al. } \\
2010\end{array}$ & $\begin{array}{l}\text { Highest cultural value intensities were } \\
\text { related to surface water and biota assets } \\
\text { for cultural services. }\end{array}$ \\
\hline
\end{tabular}


2005

Pike and San 12 landscape values; only Scenic viewsheds, vertebrate Points Isabel National aesthetic, biodiversity,

Forests, and life-sustaining

species richness, verteb

sequestration and carbon

sediment regulation, water

regulation and supply

2004-2008 Pike and San Landscape values Elevation, slope, distance to Points Isabel, typology but only results distance to water, land cover,

Shoshone, and for recretion value for and elevation-derived

Bridger-Teton Bridger Teton NF reported landform

National

\section{Forests}

Colorado and

2005

Wyoming, US

$\begin{array}{ll}\text { Pike and San Landscape values } & \text { Elevation, slope, distance to Points } \\ \text { roads, distance to water }\end{array}$ Isabel National typology

Pois

Colorado, US

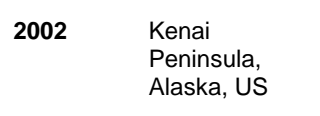

Landscape values Net primary productivity Points

typology but only results

tor biological value

reported

1998 Chugach Landscape values

National typology

US

roads

Distance from communities, Points roads
Random household (survey) $(n=684)$

Random household (survey) ( $n=359$ ) for Bridger-Teton

\section{Random household \\ (survey) ( $\mathrm{n}=684$ )}

Random household
survey) ( $n=561)$
Random household
survey) ( $n=821$ )

capital assets

regression

SoIVES 2.0 application calculates Value Index

derived from mapped

services densilies to identify

features.

SoIVES application

calculates Value Index

identify relationships with

identify relationships
physical features and

provides for value transfer

provides for value transfer
(extrapolation). Maxent

modelling integrated in latest

version.

Linear regression between standardized

standardized

NPP index and standardized

index of biological value

from density weighting

Mean distance and

cumulative frequency
distributions as a function

distance
Bagstad et al., 2015 Weak relationships

between cultural and physically modeled services; public perception of ecosystem service regions is limited

Sherrouse et al., Highly intensities of recreation values 2014 more proximate to roads and open water and occur on lower slopes in landforms such as valley flats.

Clement-Potter, Elevation and distance to roads positively 2006; Sherrouse et and significantly correlated with mapped value intensities. Slope and distance to water less strongly correlated. Areas valued highly, especially for recreation and aesthetic values.

Alessa et al., 2008; Moderately significant, positive relationships between perceived biological value and net primary productivity for six aggregated community responses.

Brown et al., 2003 Cultural values clustered near communities but distance depends on value. Recreation, aesthetic and economic values closer to roads than intrinsic, life sustaining and future values.

${ }^{a}$ Year of spatial data collection, not publication of results. 
Table 2. Ecosystem values typology with operational definitions and suggested ecosystem service category: P=Provisioning, $\mathrm{C}=$ Cultural, $\mathrm{S}=$ Supporting.

\begin{tabular}{|c|c|}
\hline Ecosystem Value & Operational definition \\
\hline (P) Hunting/fishing & Areas are important because of hunting and/or fishing. \\
\hline (P) Pastures/fodder & Areas are important because they are used for haymaking and pastures for reindeer, sheep, cows \\
\hline (P) Gathering & Areas are important for berries, mushroom or collecting herbs/plants here. \\
\hline (P) Water quality & Areas are important because they provide clean water. \\
\hline (S) Biological diversity & Areas are important because they provide a variety of plants, wildlife, and habitat. \\
\hline (C) Recreation & $\begin{array}{l}\text { Areas are important for outdoor recreation activities (e.g., camping, walking, skiing, alpine, snowmobiling, } \\
\text { cycling, horse riding etc.) }\end{array}$ \\
\hline (C) Scenic areas & Areas are important because they include beautiful nature and/or landscapes. \\
\hline (C) Culture/identity & $\begin{array}{l}\text { Areas are important because of their historical value, or for passing down the stories, myths, knowledge and } \\
\text { traditions, and/ or to increase understanding of the way of life of our ancestors. }\end{array}$ \\
\hline (C) Income I $^{a}$ & $\begin{array}{l}\text { Areas are important because they provide tourism opportunities, mining, hydroelectric power or other potential } \\
\text { sources of income. }\end{array}$ \\
\hline (C) Undisturbed nature (naturalness) ${ }^{\mathbf{a}}$ & Areas are relatively untouched, providing for peace and quiet without too many disturbances. \\
\hline (C) Social ${ }^{\mathrm{b}}$ & $\begin{array}{l}\text { Areas are important because they provide opportunities for social activities (e.g. associated with fireplaces, } \\
\text { picnic tables, ski -or alpine arrangements, shelters, shared cabins, cabin complexes). }\end{array}$ \\
\hline (C) Spiritual & $\begin{array}{l}\text { Areas are important because they are valuable in their own right or have a deeper meaning; emotionally, } \\
\text { spiritually, or religious. }\end{array}$ \\
\hline (C) Therapeutic/health & $\begin{array}{l}\text { Place are valuable because they make me feel better, either because they provide opportunities for physically } \\
\text { activities important for my health and/or they give me peace, harmony and therapy }\end{array}$ \\
\hline (C) Special places & Please describe why these places are special to you. \\
\hline \multicolumn{2}{|c|}{$\begin{array}{l}\text { The income and undisturbed nature categories are not specifically listed in the MA, TEEB, or CICES classifications but these values are related to existing } \\
\text { service categories. For example, income may be derived from ecotourism (MA) and tourism (TEEB) activities. However, in the Norwegian context, income can } \\
\text { also be generated from forestry, grazing, and hydroelectric power development. The undisturbed nature (naturalness) value is related to aesthetics and inspiration } \\
\text { services (MA, TEEB). All of the mapped values need to relate to ecosystem features to be defined as ecosystem values. } \\
\text { b The social category is identified in the MA report as a "social relations" cultural service wherein ecosystems influence the types of social relations that are } \\
\text { established in particular cultures. }\end{array}$} \\
\hline
\end{tabular}


Table 3. Participation statistics and respondent characteristics for two study areas.

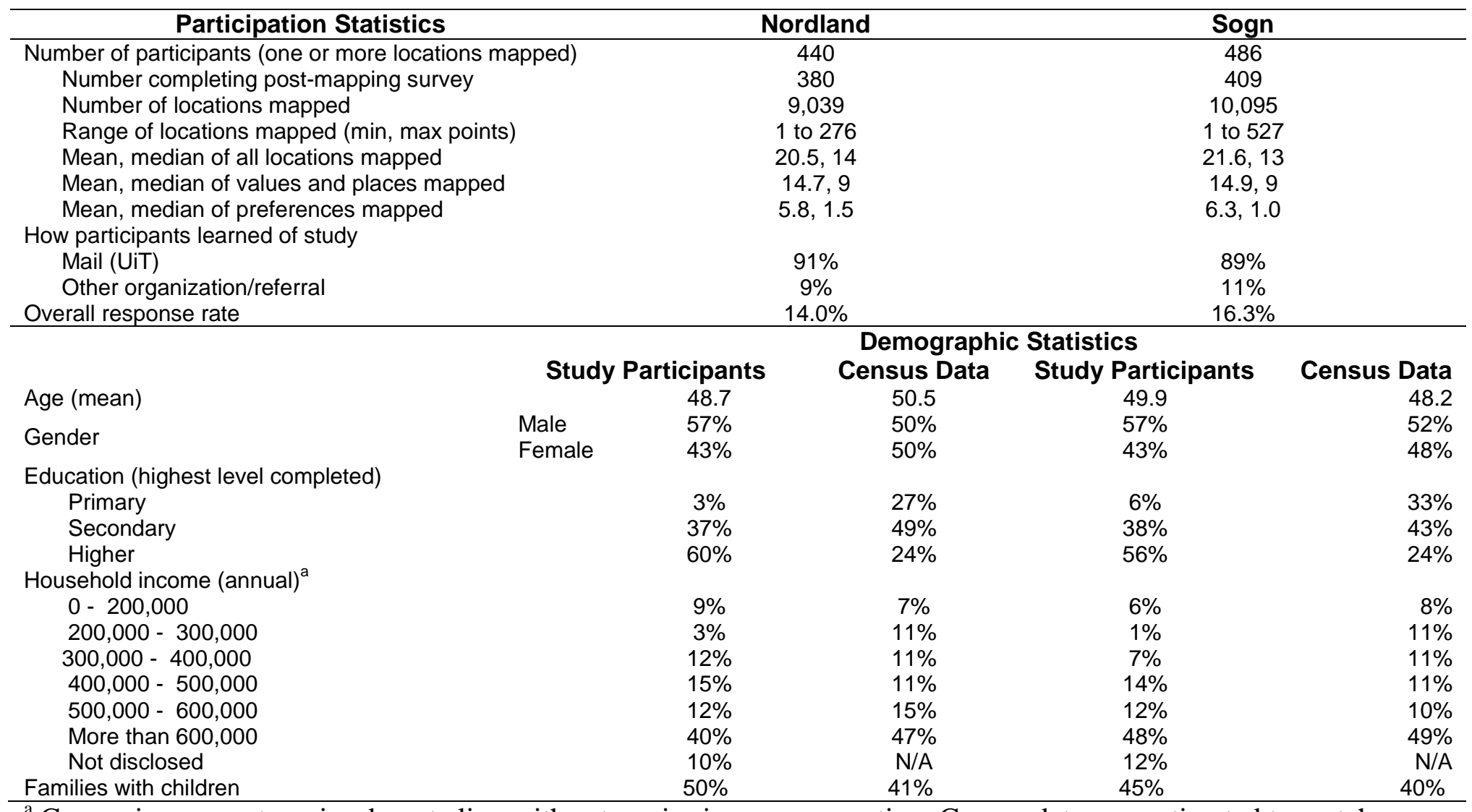

${ }^{a}$ Census income categories do not align with categories in survey question. Census data was estimated to match survey data. 
Table 4. Results of factor analysis of spatial distribution of ecosystem values (marker counts per $2 \mathrm{~km}^{2}$ ) using principal components extraction (PCA) with varimax rotation for combined Nordland and Sogn study areas. Four factors account for 52\% of the overall variance. Largest item loadings on each factor are highlighted.

\begin{tabular}{lcccc}
\hline Nordland and Sogn & \multicolumn{4}{c}{ PCA Component / Ecosystem Service Bundle } \\
& 1 & 2 & 3 & 4 \\
& $(\lambda=3.8,27 \%)$ & $(\lambda=1.4,10 \%)$ & $(\lambda=1.2,8 \%)$ & $(\lambda=1.0,7 \%)$ \\
\hline Thematic content & Place & Recreation/ & Naturalness & Provisioning \\
& socialization & & \\
\hline Hunting/fishing & .353 & -.296 & .326 & .482 \\
Pastures/grazing & .158 & .086 & -.179 & .637 \\
Gathering & -.086 & .228 & .153 & .638 \\
Water quality & -.013 & -.021 & .524 & .266 \\
Biological diversity & .172 & .039 & .591 & -.048 \\
Recreation & -.058 & .583 & .453 & .418 \\
Scenic areas & .299 & .388 & .524 & .188 \\
Culture/identity & .716 & .310 & .078 & .079 \\
Income & .685 & .322 & -.053 & .109 \\
Undisturbed nature & .120 & .137 & .639 & -.145 \\
Social & .378 & .731 & .052 & .146 \\
Spiritual & .592 & .051 & .138 & -.069 \\
Therapeutic/health & .245 & .749 & .089 & .027 \\
Special places & .598 & .041 & .255 & .103 \\
\hline
\end{tabular}


Table 5. Spearman's rank correlation coefficients between ecosystem service bundles (rows) and land cover type (columns) located in $2 \mathrm{~km}^{2}$ grid cells $(\mathrm{n}=3030)$. Significant positive correlations are highlighted in green, negative correlations in red.

\begin{tabular}{|c|c|c|c|c|c|c|c|c|c|c|c|c|}
\hline Ecosystem bundle & $\begin{array}{l}50 \text { Closed } \\
\text { broad } \\
\text { leaved } \\
\text { deciduous }\end{array}$ & $\begin{array}{l}70 \text { Closed } \\
\text { needle } \\
\text { leaved } \\
\text { evergreen }\end{array}$ & $\begin{array}{c}90 \text { Open } \\
\text { needle leaved } \\
\text { deciduous or } \\
\text { evergreen }\end{array}$ & $\begin{array}{l}100 \text { Closed to } \\
\text { open mixed } \\
\text { broad leaved } \\
\text { and needle } \\
\text { leaved }\end{array}$ & $\begin{array}{c}110 \\
\text { Mosaic } \\
\text { forest- } \\
\text { shrubland } \\
\text { grassland }\end{array}$ & $\begin{array}{c}120 \\
\text { Mosaic } \\
\text { grassland } \\
\text { forest } \\
\text { shrubland }\end{array}$ & $\begin{array}{l}150 \text { Sparse } \\
\text { vegetation }\end{array}$ & $\begin{array}{l}180 \text { Closed } \\
\text { to open } \\
\text { vegetation } \\
\text { regularly } \\
\text { flooded }\end{array}$ & $\begin{array}{c}190 \\
\text { Artificial/ } \\
\text { develope } \\
\text { d areas }\end{array}$ & $\begin{array}{l}200 \\
\text { Bare } \\
\text { areas }\end{array}$ & $\begin{array}{l}210 \\
\text { Water } \\
\text { bodies }\end{array}$ & $\begin{array}{c}220 \\
\text { Permanent } \\
\text { snow and ice }\end{array}$ \\
\hline Place identity/dependence & .019 & $.095^{2 * a}$ & .013 & -.006 & -.025 & -.024 & -.019 & -.053 & .047 & -.003 & $.095^{*}$ & .004 \\
\hline Recreation & .095 & .008 & .073 & .093 & .130 & .120 & -.079 & .059 & .055 & -.074 & .004 & -.010 \\
\hline Naturalness & -.024 & -.019 & .033 & -.024 & .035 & .019 & .081 & .082 & -.045 & -.018 & .027 & -.023 \\
\hline Provisioning & .138 & -.015 & .098 & .122 & .118 & .125 & -.011 & .071 & -.029 & -.173 & .035 & 136 \\
\hline
\end{tabular}

a significance levels: $* * \mathrm{p} \leq .01, * \mathrm{p} \leq .05$ 
Table 6. Indices used to "value transfer" the spatial distribution of recreation values in Nordland to Sogn. The "actual" column is based on the spatial distribution of mapped recreation values associated with land cover classes in Sogn. The "transfer" column contains spatial associations with land cover classes in Nordland that were used to generate the maps shown in Figure 7.

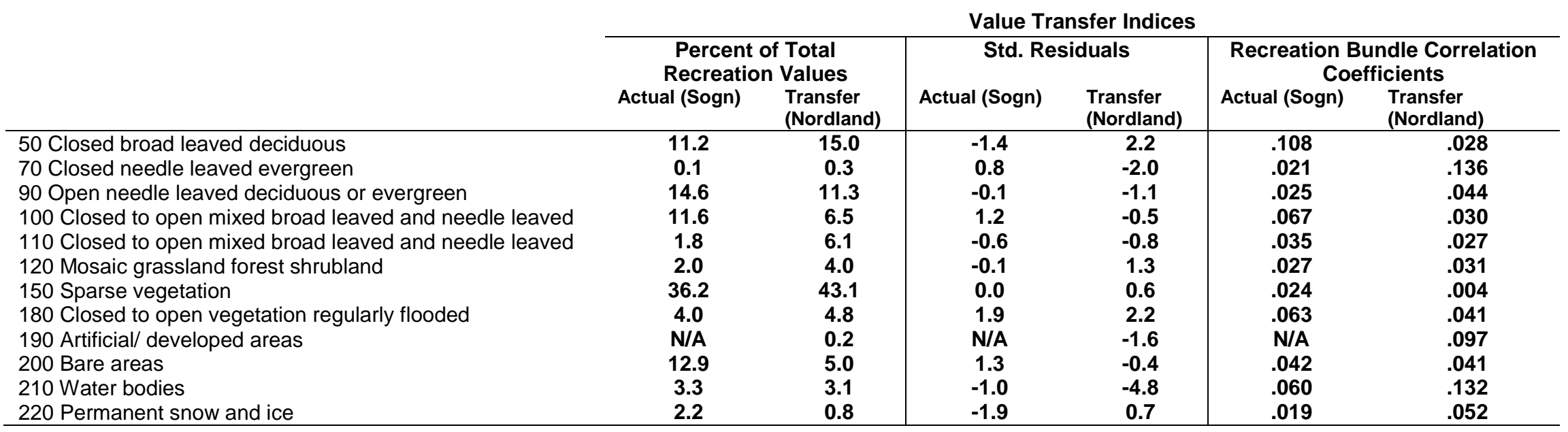




\section{Figure 1}

Two study areas located in: (a) southern Norway (Sogn), and (b) northern Norway (Nordland). Maps show land tenure and the number of study participants by geographic location.
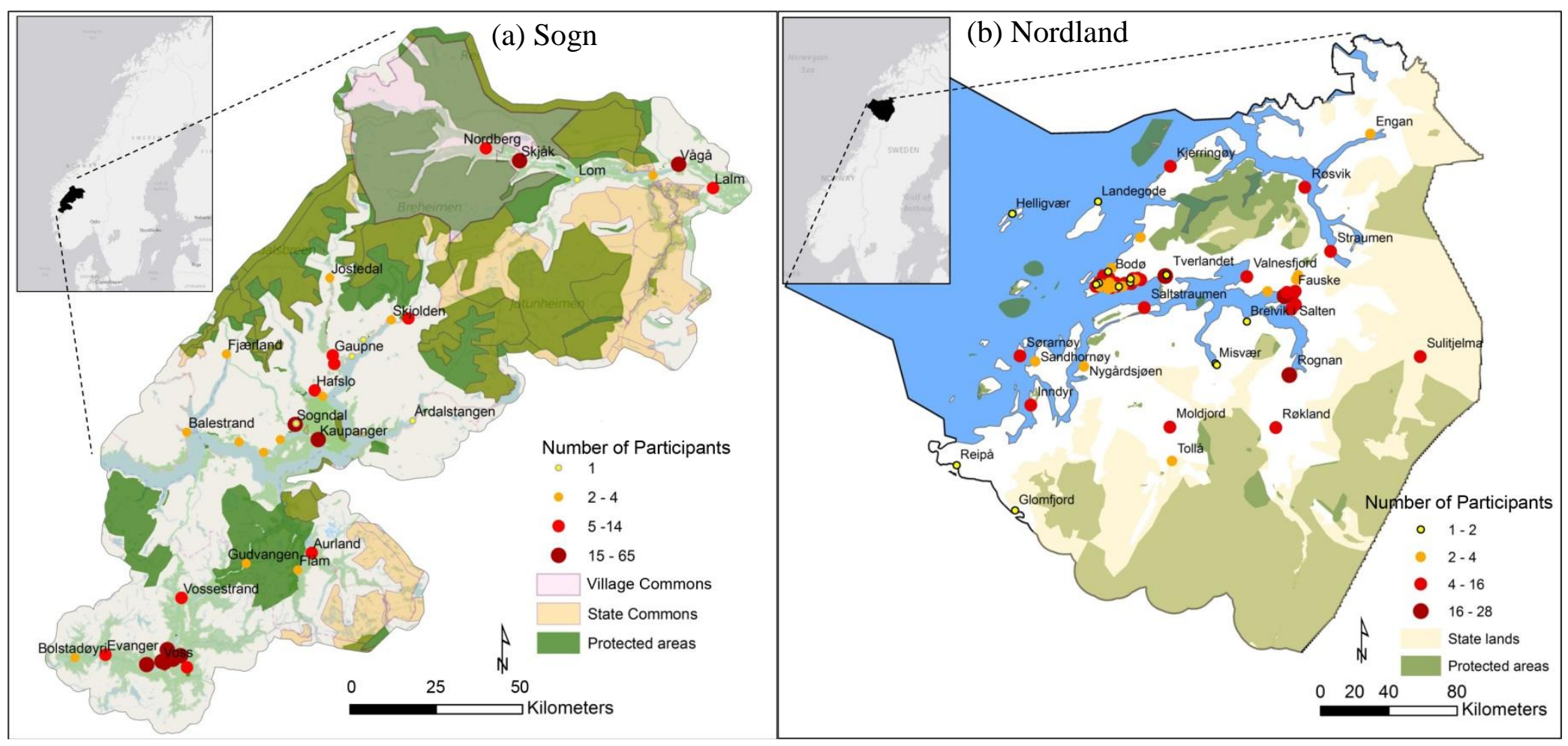


\section{Figure 2}

Distribution of global land cover classes (terrestrial, non-water) compared to distribution of classes located within Nordland and Sogn study areas, along with the percentage of ecosystem value points mapped by land cover class.

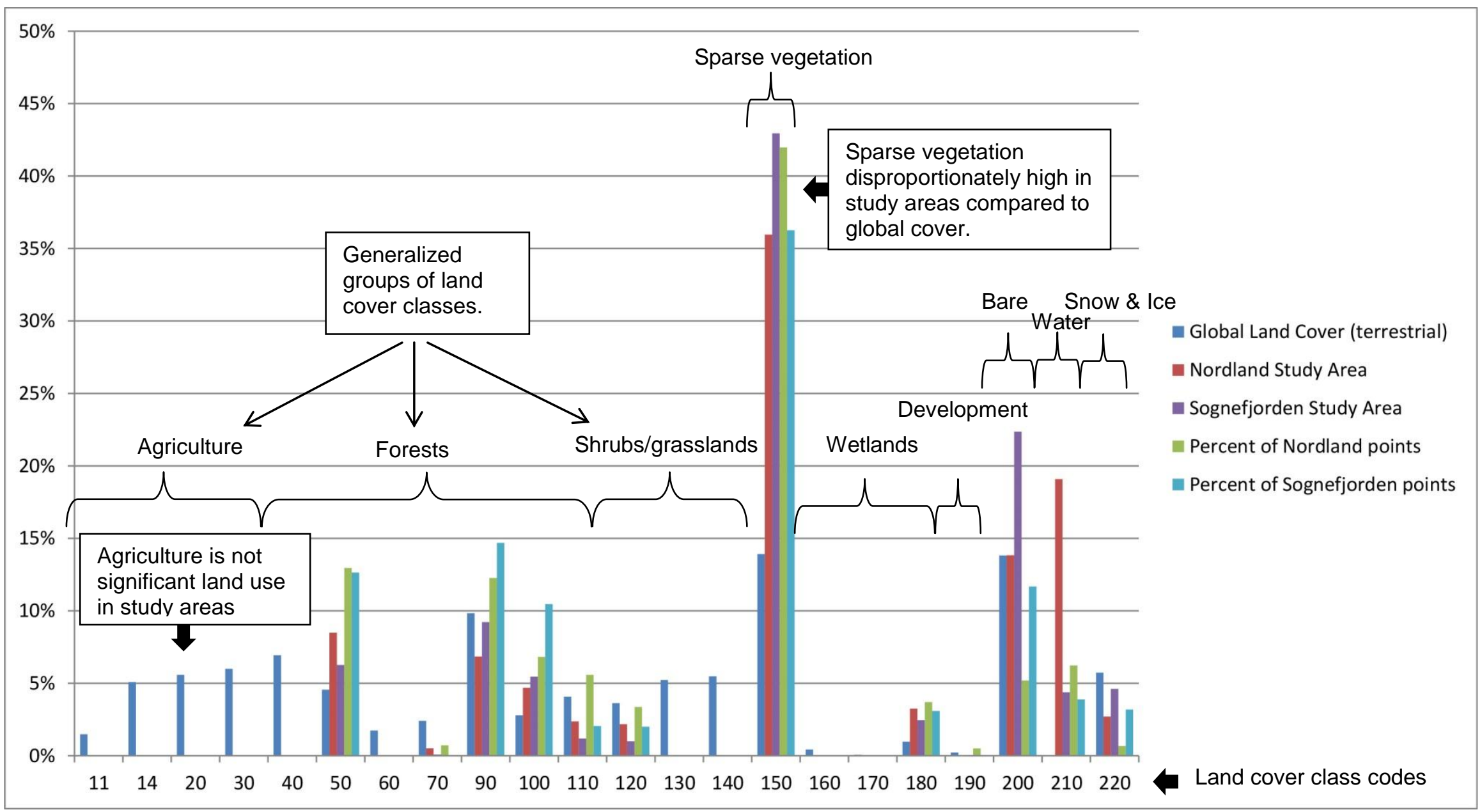




\section{Figure 3}

Z-scores (y-axis) of ecosystem values by land cover class (x-axis) in Nordland. Z-scores greater than +1.96 or less than -1.96 indicate that value distribution differs significantly from what would be expected based on proportion of land cover class within the study area.

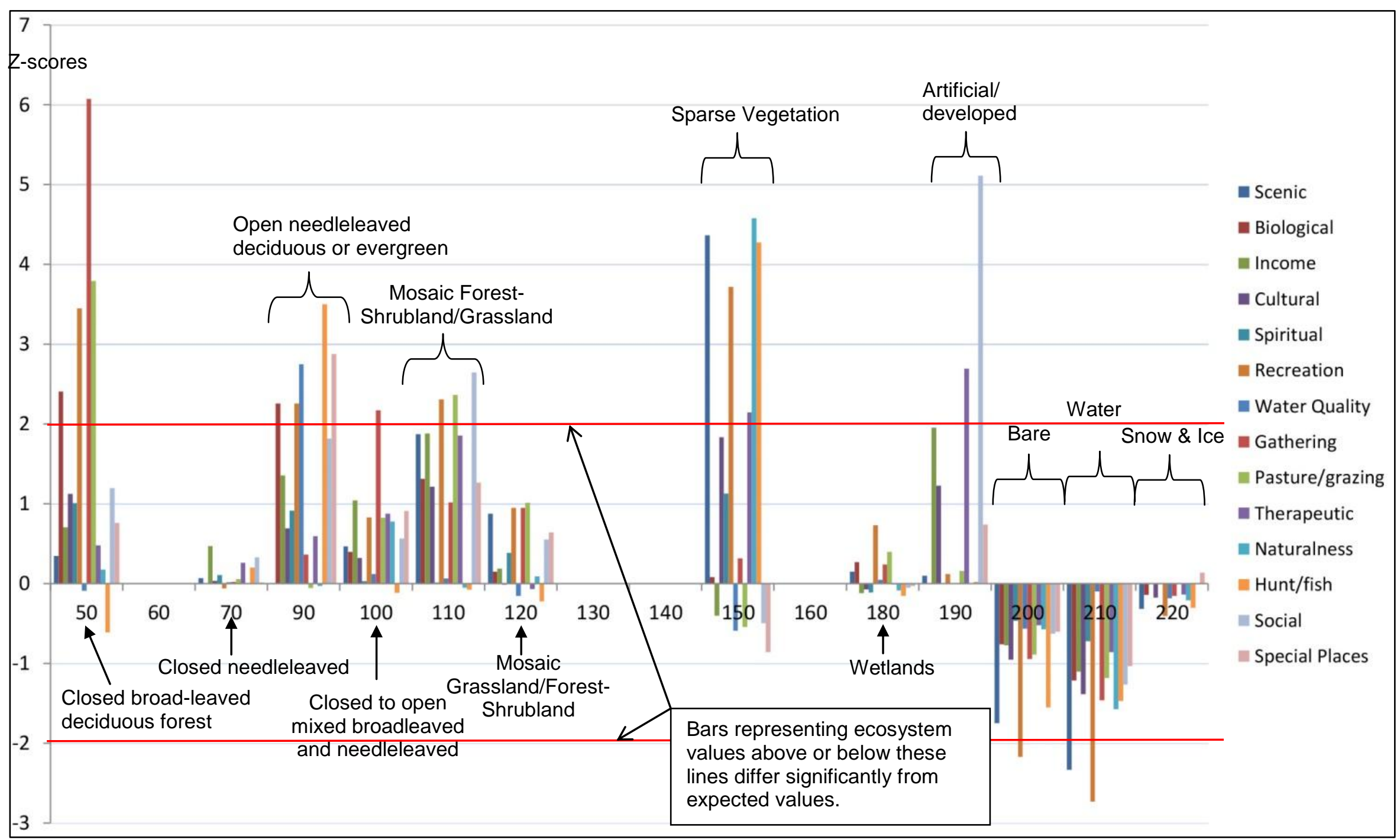




\section{Figure 4}

Z-scores (y-axis) of ecosystem values by land cover class (x-axis) in Sogn. Z-scores greater than +1.96 or less than -1.96 indicate that value distribution differs significantly from what would be expected based on proportion of land cover class within the study area.

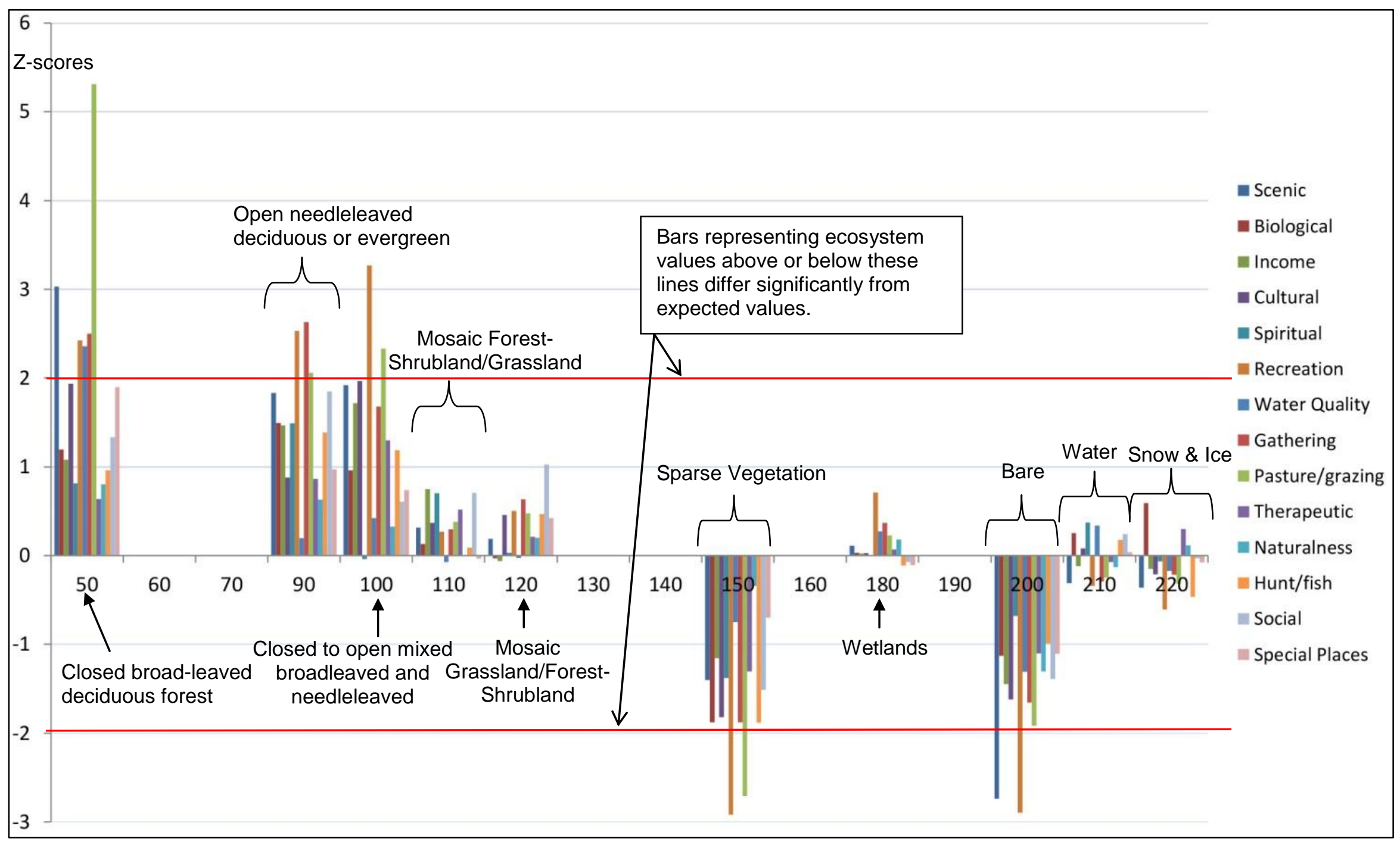

